Іващенко А. М. к.т.н., доцент

Центр воєнно-стратегічних досліджень Національного університету оборони України імені Івана Черняховського, Київ

\title{
Мета і напрями діяльності Північноатлантичного Альянсу 3 підтримки сектору безпеки і оборони країн-партнерів
}

Резюме. Проводено аналіз концепції і заходів Північноатлантичного Альянсу, що стосується підтримки та розвитку спроможностей сил безпеки (Security Force Assistance) і оборони країн-партнерів HATO.

Ключові слова: Північноатлантичний Альянс; спроможності сектору безпеки і оборони; підтримка сил безпеки; концепція; доктрина; радники; бригада підтримки сил безпеки; центр передового досвіду.

Постановка проблеми. Асиметричні війни, які понад двадцять років тривають на території Іраку, Афганістану і Сирії, гібридна агресія Росії проти України, вимагають пошуку принципово нових форм і способів досягнення цілей в сучасних воєнних конфліктах. Одним з напрямів протидії новим загрозам $\mathrm{i}$ забезпечення безпеки Північноатлантичний Альянс розглядає підтримку і розвиток спроможностей сектору безпеки і оборони (Security Force Assistance, SFA) країн-партнерів, які не є членами НАТО. Аналіз можливостей застосування нової концепції для забезпечення безпеки України є актуальним.

Аналіз основних досліджень i публікацій. Офіційні матеріали трьох останніх самітів НАТО (Лісабон, 2010 р.; Уельс 2014 р., Варшава 2016 р.); концепція [4], доктрина [5] і керівництво [6] НАТО визначають засади підтримки сил безпеки країн-партнерів. Окремим аспектам цього проблемного питання присвячена низка статей військових аналітиків і експертів [11-12]. У процесі підготовки статті публікацій українських авторів 3 цього питання не виявлено. Стаття, що пропонується, у першу чергу зосереджує свою увагу на заходах імплементації концепції підтримки сил безпеки.

Метою статті $\epsilon$ аналіз заходів імплементації концепції НАТО 3 підтримки сил безпеки.

\section{Виклад}

\section{основного}

Відповідно до Стратегічної

матеріалу. Північноатлантичного Альянсу [1], в інтересах забезпечення оборони i безпеки своїх членів, НАТО зосереджує діяльність на вирішенні трьох основних завдань:

колективна оборона відповідно до статі 5 Вашингтонського договору про зобов'язання країн-учасниць надавати одна одній допомогу в разі нападу на будь-кого 3 них;

врегулювання криз відповідно до чинної концепції кризового врегулювання, яка передбачає комплексне використання відповідних політичних і воєнних інструментів на всіх етапах розвитку конфлікту: зародження, врегулювання, ліквідації наслідків збройного протиборства;

забезпечення безпеки на основі співробітництва і розвитку взаємодії з іншими міжнародними організаціями і країнами, що не $\epsilon$ членами Альянсу за такими напрямами: посилення контролю над озброєннями, сприяння роззброєнню та формуванню режиму нерозповсюдження зброї масового ураження, продовження процесу розширення організації в рамках політики “відкритих дверей”, вдосконалення системи партнерських відносин.

Саміт НАТО у Великобританії [2] визначив ще один напрям діяльності Альянсу, направлений на зміцнення спроможностей сектору безпеки і оборони країн-партнерів, які не $\epsilon$ членами Альянсу. Нова ініціатива отримала назву "підтримка сил безпеки i оборони” (Security Force Assistance, SFA).

Підводячи дворічний підсумок імплементації SFA, комюніке Варшавського саміту відмічає, що SFA дав змогу посилити роль Альянсу в забезпеченні комплексного підходу до питань безпеки і стабільності в сучасних умовах шляхом підтримки заходів 3 розвитку спроможностей сектору безпеки i оборони в країнах-партнерах Альянсу [3].

Для реалізації нової ініціативи Альянсом розроблені та впроваджуються такі керівні документи:

концепція SFA [4];

доктрина SFA [5];

керівництво з SFA [6].

Крім того, окремі питання SFA викладені в концепціях стратегічного рівня, таких як 
"Розвиток спроможностей оборони і безпеки" [7], “Завдання розвитку спроможностей оборони і безпеки" [8], "Плани дій щодо всебічного підходу" [9].

Відповідно до керівних документів, під SFA розуміється спроможність "тренувати та розвивати національні сили в кризових зонах" 3 метою “досягнення національними органами влади країн-партнерів спроможностей щодо ефективної підтримки безпеки без міжнародної допомоги” [4]. До SFA віднесено "всі дії НАТО, які розвивають, вдосконалюють або безпосередньо підтримують розвиток начіональних сил безпеки та оборони та їх асоиійованого iнституту" [5]. Таким чином, у загальному контексті, SFA охоплює всі заходи, спрямовані на розвиток i підготовку національного сектору безпеки i оборони $\mathrm{i}$ проводиться на тактичному, оперативному, стратегічному та воєнно-політичному рівнях, передбачає надання консультативної допомоги від окремого взводу до міністерства. У більш широкому контексті, SFA, хоч і має воєнну спрямованість, містить такі механізми запобігання сучасним воєнним конфліктам, як політичні, економічні, інформаційні, правові тощо.

3 метою імплементації SFA керівництвом Альянсу та окремими країнамичленами НАТО проведено ряд практичних заходів.

Так, штаб-квартирою НАТО сформована спеціальна група радників, які направляються в оборонні відомства країнпартнерів. Першим учасником цього проекту розглядалися Грузія, Йорданія i Молдова. Наприкінці 2015 року, у зв'язку з агресією Росії, НАТО ініціювало створення об'єднаної багатонаціональної групи 3 підготовки підрозділів для Збройних Сил і Національної гвардії України (Joint Multinational Training Group - Ukraine), до якої входять радникі від збройних сил США, Великої Британії, Канади, Польщі, Естонії, Литви i Латвії. Група розміщена на території Міжнародного центру миротворчої діяльності та безпеки у Львівській області. При вирішенні завдань SFA в Україні керівництво Північноатлантичного союзу також активно використовує потенціал ООН, СС і ОБСЕ [10].

США почали формування шести бригад сприяння безпеці (SFABs), основним завданням яких $\epsilon$ проведення тренінгів, надання консультацій, сприяння, забезпечення та супроводження операцій 3 коаліційними силами та країнами-партнерами. Ці підрозділи складаються головним чином 3 офіцерів, які призначаються 3 штатних армійських підрозділів та закінчили Академію воєнних радників у форті Беннінг, штат Джорджія [11]. На думку воєнних експертів США, SFABs дають змогу досягти таких стратегічних цілей [12]:

розвиток спроможностей сил безпеки i оборони країн-партнерів;

звільнення штатних бойових армійських бригад від невластивих їм функцій;

забезпечення, у разі необхідності, підготовки інфраструктури країн-партнерів для сил швидкого реагування Альянсу.

Діючи концепції, керівництва і статути збройних сил США розглядають SFA як окремий вид операції, який проводиться силами спеціальних операцій (ССО). Комплектування і підготовку першої бригади SFAB планується завершити у травні 2018 року та направити для вирішення завдань SFA в Афганістан.

Урядом Італії у травні 2017 року прийнято рішення про організацію Центру передового досвіду НАТО з питань підтримки сил безпеки (NATO Security Force Assistance Centre of Excellence) та його розташування у столиці країни [13]. На Центр покладаються такі завдання:

поєднання зусиль країн-членів та партнерів НАТО щодо розвитку спроможностей, підвищення оперативної сумісності, стандартизації та ефективності в галузі SFA;

сприяння комплексному підходу та ефективному використанню спільного досвіду та спроможностей;

надавання експертизи та консультації 3 питань, що стосуються SFA;

розроблення політики, стандартів та інших керівних документів із питань SFA; надання підтримки 3 планування та проведення заходів, навчань і операцій Альянсу в частині питань SFA;

аналіз досвіду операцій SFA, підтримка та актуалізація баз даних із питань SFA;

цільова підготовка військового і цивільного персоналу, а також підрозділів та груп із питань SFA;

направлення мобільних навчальних команд для сприяння освіті та підготовці національних та багатонаціональних військових і цивільних структур.

Передбачається, що Центр передового досвіду пройде сертифікацію та приступить до виконання завдань наприкінці 2018 року. 
На тактичному рівні, у відповідності до стандартів Альянсу, в рамках SFA вирішуються такі завдання:

організація і проведення, відповідно до прийнятих в НАТО нормативів, цільових інструкторсько-методичних занять 3 підрозділами зі складу загальновійськових з'єднань, десантно-штурмових бригад, а також бойових груп сил спеціальних операцій;

ознайомлення військовослужбовців країн-партнерів 3 новими зразками озброєння, військової техніки, засобами зв'язку та навігації, іншим спеціальним обладнанням; визначення рівня готовності формувань до бойових дій $з$ урахуванням прийнятих в Альянсі нормативів.

Підготовка

військовослужбовців загальновійськових і десантно-штурмових формувань спрямована на вдосконалення професійних навичок, що застосовуються при веденні підрозділом дій в обороні та наступі. При цьому особливий акцент робиться на підвищенні індивідуальної польової виучки офіцерів і солдатів країн-партнерів.

Після закінчення навчального курсу уповноважені представники НАТО проводять атестацію (сертифікацію) підготовлених формувань національної армії і органів військового управління на предмет їх відповідності прийнятим в Альянсі стандартам.

Як правило, до заходів SFA залучаються викладачі військово-навчальних закладів i учбових центрів, начальники загальновійськових полігонів і командири військових частин. Ця категорія військовослужбовців цілеспрямовано вивчає прийняту в Альянсі методику організації занять $з$ оперативної і бойової підготовки для подальшого впровадження отриманих знань у навчальну практику на місцях.

Особлива увага приділяється розвитку спроможностей ССО країн-партнерів. При цьому враховується високі оперативні спроможності спецпідрозділів, призначених для виконання важливих завдань, у тому числі в умовах гібридних конфліктів. Підготовка військовослужбовців підрозділів $\mathrm{CCO}$ здійснюється, виходячи із загальної специфіки застосування підрозділів (груп) спецпризначення в інтересах досягнення конкретних воєнно-політичних $\mathrm{i}$ воєнних цілей. Зокрема, це знищення стратегічних об'єктів супротивника, його ракетно-ядерної і ракетної зброї, ведення радіоелектронної розвідки, організація повстанського i партизанського рухів, проведення диверсій і терористичних представників керівництва актів, ліквідація ключових державного i військового протиборчої сторони. Впровадження передових методів і способів проведення спецзаходів відбувається 3 урахуванням досвіду, отриманого в ході воєнних конфліктів.

Поряд 3 цим, радники навчають особовий склад $\mathrm{CCO}$ країн-партнерів особливостям проведення інформаційно-психологічних операцій, організації пропагандистських заходів, введенню супротивника в оману, інформуванню мирного населення i дискредитації органів влади протиборчої сторони.

В інтересах закріплення досягнутих формуваннями країн-партнерів результатів бойового навчання, а також для визначення ступеня їх готовності до дій у складі багатонаціональних сил Альянсу щорічно проводяться багатонаціональні навчання. Їхній сценарій, як правило, передбачає виникнення в умовному регіоні кризових ситуацій, вирішення яких вимагає втручання сил Альянсу.

Поряд 3 наданням допомоги в навчанні особового складу країн-партнерів на національній території, SFA надає можливість направляти військовослужбовців до навчальних закладів своїх країн. Навчання військових i цивільних фахівців сектору безпеки і оборони здійснюється за такими напрямами: інформаційна та кібербезпека, проведення миротворчих операцій, міжнародна i національна безпека, розвідувальна діяльність, військова медицина, штабна i інженерна підготовка, підвищення кваліфікації офіцерів військової поліції, підготовка молодшого командного складу, вивчення іноземних мов, підготовка фахівців кадрових органів тощо.

Крім того, військовослужбовці країнпартнерів активно залучаються до проведення спільних 3 Північноатлантичним союзом заходів оперативної і бойової підготовки на території країн Альянсу. У ході цих навчань, як правило, значна увага приділяється питанням організації роботи об'єднаного штабу 3 метою всебічного забезпечення дій багатонаціонального формування.

Проведення під керівництвом радників заходів SFA, в тому числі навчань із залученням підрозділів сухопутних військ, повітряних i військово-морських сил, високомобільних десантних військ, сил спеціальних операцій, а також національної гвардії, дають змогу вирішити такі завдання: 
підвищити рівень професійного вишколу військовослужбовців, перш за все зі складу загальновійськових 'єднань, бригад десантно-штурмових бригад і морської піхоти;

3 використанням досвіду збройних сил країн НАТО розвинути спроможності ССО країн-партнерів, а також спецпідрозділів інших структур сектору безпеки і оборони;

забезпечити постійну присутність на території країни-партнера контингенту військовослужбовців, у середньому від 500 до 900 осіб об'єднаних збройних сил НАТО в якості радників і інструкторів.

Поряд 3 цим актуальним $\epsilon$ питання удосконалення нормативно-законодавчої бази, відповідно до якої чисельність іноземних військових радників може бути при необхідності суттєво збільшена до кількох тисяч осіб на весь термін проведення операції SFA.

У перспективі країни НАТО, зацікавлені в поглибленні співпраці в оборонній сфері, планують продовжити надання допомоги в питаннях професійної підготовки військовослужбовців країн-партнерів, оптимізації організаційно-штатної структури та чисельності національних збройних сил, модернізації системи управління, тилового, технічного та медичного забезпечення. Подібна взаємодія дає змогу НАТО водночас 3 предметним вивченням умов потенційного театру воєнних дій, знайомитися 3 досвідом, отриманим військовослужбовцями країнпартнерів при виконанні ними бойових завдань у ході воєнних конфліктів, з метою його всебічного аналізу та використання при підготовці об' єднаних збройних сил Альянсу.

Для цього визначені такі завдання: бойова і оперативна підготовка національних підрозділів, підготовка інструкторів 3 числа військовослужбовців національних збройних сил, надання сприяння в обладнанні навчальних центрів на території країнпартнерів, консультативна допомога в питаннях реформування збройних сил та їх послідовного приведення до стандартів HATO.

\section{Висновки.}

Північноатлантичний Альянс дієву концепцію підтримки чином, впроваджує i розвитку спроможностей сектору безпеки і оборони та практичні механізми ії імплементації, які дають змогу розв'язати широке коло проблем забезпечення безпеки і оборони країн, які не $\epsilon$ членами НАТО. Разом 3 тим, впровадження такої концепції вимагає від країн-партнерів змін нормативно-правової бази та відповідної підготовки інфраструктури.

У подальшому буде проведено аналіз окремих механізмів імплементації концепції підтримки сил безпеки на оперативному i стратегічному рівнях.

\section{СПИСОК ВИКОРИСТАНОЇ ЛІТЕРАТУРИ}

1. Lisbon Summit Declaration, 2010; PO (2010) 0169, Strategic Concept for the Defence and Security of the Members of the North Atlantic Treaty Organization, dated 19 November 2010.

2. Wales Summit, 2014.

3. Warsaw Summit Communiqué Issued by the Heads of State and Government participating in the meeting of the North Atlantic Council in Warsaw 8-9 July 201609 Jul. 2016. Press Release (2016) \#100 Issued on 09 Jul. 2016 http://www.nato.int/cps/en/natohq/official_texts_133169.htm.

4. MCM-0034-2014, NATO Security Force Assistance Concept, dated 28 March 2014.

5. AJP-3.16 Allied Joint Doctrine for Security Force Assistance, Edition A Version 1.

6. NATO Special Operational Forses. Military Assistance HandBook.

7. Defence and Related Security Capacity Building Initiative (DCB); $\mathrm{PO}(2013) 0590$-rev.1.

8. Tasking on Defense and Related Security Capacity Building, 02 December 2013; PO (2010) 0169.

9. PO (2011) 0045. Updated List of tasks for the Implementation of the Comprehensive Approach Action Plan and the Lisbon Summit Decisions on the Comprehensive Approach, 04 March 2011.

10. Monitoring Ukraine's Security Governance Challenges. Proceeding from the First International Conference 21-22 January 2016, Kyiv, Ukraine 100 p.

11. The Department of the Army announced today the creation of a new type of organization designed to focus on security force assistance, as well as an academy that will train soldiers assigned to these specialized units. Режим доступу: https://www.army.mil/article/ 182646.

12. Ball T. Replaced Security Force Assistance Brigades vs. Special Forces. Режим доступу: https://warontherocks.com/2017/02.

13. Concept of the NATO Security Force Assistance Centre of Excellence. Version as of 2nd May, 2017. $22 \mathrm{p}$. 
Иващенко А. М., к.т.н., доцент

Центр военно-стратегических исследований Национального университета обороны Украины имени Ивана Черняховского, Киев

Цель и направления деятельности Североатлантического Альянса по поддержке сектора безопасности и обороны стран-партнеров

Резюме. Проведен анализ имплементации концепции Североатлантического Альянса "Security Force Assistance" по поддержке и развитию возможностей сектора безопасности и обороны стран-партнеров HATO.

Ключевые слова: Североатлантический Альянс; сектор безопасности и обороны; возможности; поддержка сил безопасности; советники; бригада поддержки сил безопасности; центр передового опыта.

\section{A. Ivashchenko, PhD (Technical), assistant professor}

Center for Military and Strategic Studies of the National Defence University of Ukraine named after Ivan Cherniakhovskyi, Kyiv

Purpose and activities of the North Atlantic Alliance for Assistance security and defense sectors of partner countries

Resume. An analysis of the concept and doctrine of the North Atlantic Alliance "Security Force Assistance" to support and develop the capabilities of the security and defense sectors of NATO partner countries is underway.

Keywords: North Atlantic Alliance; security and defense sector; capabilities; security forces assistance; advisers; center of excellence. 